\title{
NEPHELOMETRIC DETERMINATION OF MICROGRAM QUANTITIES OF SULFATE WITH 2-AMINOPERIMIDINE
}

E. W. BAUMANN
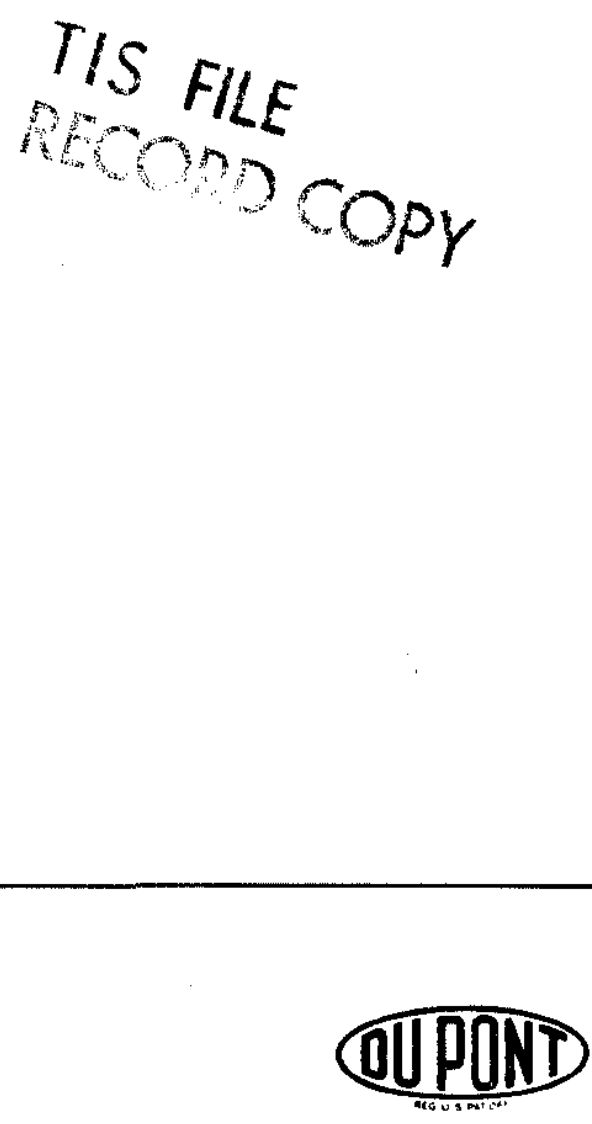

SAVANNAH RIVER LABORATORY AIKEN, SOUTH CAROLINA 29801 


\section{NOTICE}

This report was prepared as an account of work sponsored by the United States Government. Neither the United Stotes nor the United States Energy Research and Development Administration, nor any of their contractors, subcontractors, or their emplayees, makes any warranty, exprass or implied, or assumes any legal liability or responsibility for the accuracy, completeness or usefulness of any information, apparatus, product or process disclosed, or represents that its use would not infringe privatelv owned rights.

Printed in the United States of America

Available from

National Technical Information Service

U.S. Department of Commerce

5285 Port Royal Road

Springfleld, Virginia 22161

Price: Printed Copy $\$ 3.50$; Microflche $\$ 2.25$ 


\section{NEPHELOMETRIC DETERMINATION OF MICROGRAM QUANTITIES OF SULFATE WITH 2-AMINOPERIMIDINE}

by

ELIZABETH W. BAUMANN

Approved by

R. L. Folger, Research Manager

Analytical Chemistry Division

Publication Date: September 1976

E. I. DU PONT DE NEMOURS AND COMPANY SAVANNAH RIVER LABORATORY

AIKEN, SOUTH CAROLINA 29801

PREPARED FOR THE U. S. ENERGY RESEARCH AND DEVELOPMENT ADMINISTRATION UNDER CONTRACT ATIO7-21.1 
Sulfate was determined nephelometrically with 2-aminoperimidine sulfate suspensions at $\mathrm{pH} 2$. The method was applicable from 2 to $30 \mu \mathrm{g}$ of sulfate in $20 \mathrm{~m} 1$ of sample, with an estimated relative precision of $10 \%$. Procedures for purification and recovery of the 2aminoperimidine hydrochloride reagent are given. After colored organic material was removed by a column of the polymeric adsorbent Amberitite* XAD-2, the sulfate content of surface waters was determined with this method.

* Trademark Rohm and Haas Company, Philadelphia, PA. 


\section{CONTENTS}

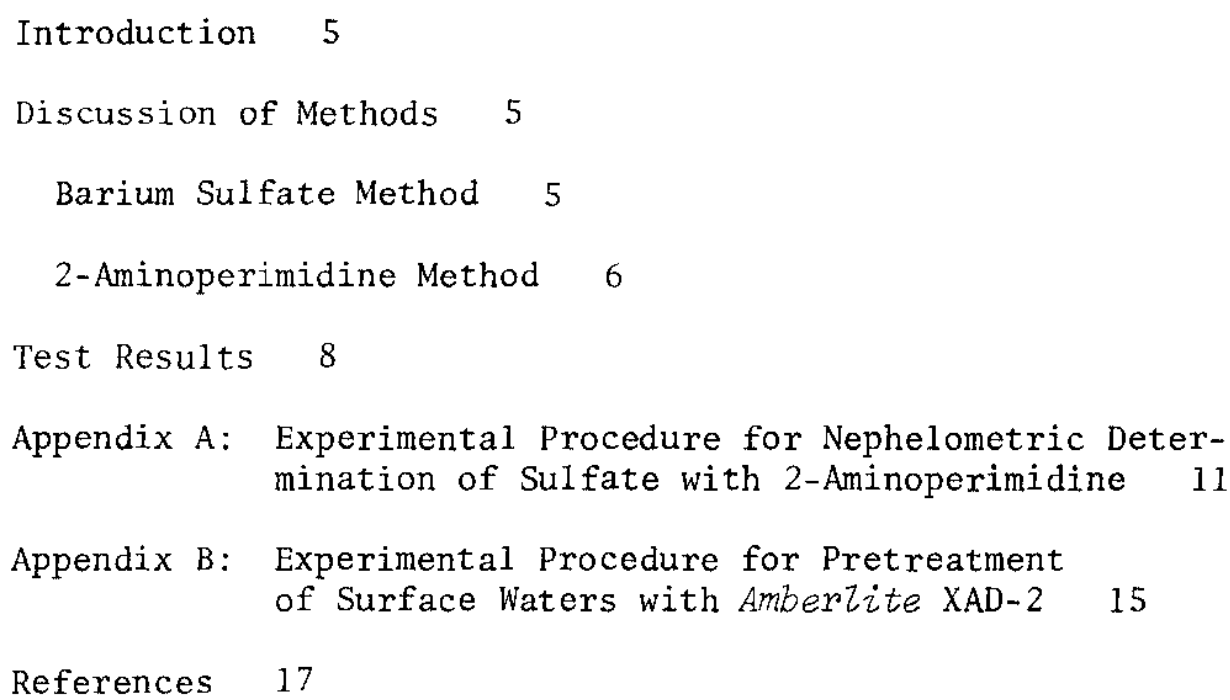




\title{
NEPHELOMETRIC DETERMINATION OF MICROGRAM QUANTITIES OF SULFATE WITH 2-AMINOPERIMIDINE
}

\author{
INTRODUCTION
}

A continuing need exists for a simple reliable method of determining low-level sulfate concentrations in aqueous systems. Most classical methods are based on precipitation of sulfate as the sparingly soluble barium sulfate. Sulfate is then determined directly from the turbidity of barium sulfate suspensions or indirectly through determination of the bound or excess barium ion associated with the barium sulfate precipitation. These methods are limited in usefulness by the nature of the barium sulfate precipitate. Stable, reproducible suspensions are difficult to obtain; and the barium sulfate precipitate is seldom stoichiometric and without occluded ions. ${ }^{1}$

A new reagent for sulfate, 2-aminoperimidine (2AP), was described, and its use for a more sensitive nephelometric method was suggested. ${ }^{2}$ Small uniform crystals of $2 A P$ sulfate form a reproducible suspension suited to analytical measurement. This insoluble sulfate has been used, also, as the basis for sulfate determination by spectrophotometry ${ }^{3}$ and pyrolysis. ${ }^{4}$

The nephelometric* method with $2 \mathrm{AP}$ offers more sensitivity than the barium sulfate turbidimetric ${ }^{*}$ method with the same experimental simplicity. It was investigated particularly for application to analysis of surface waters at the Savannah River plant (SRP). These waters are continually monitored for sulfate, but have a sulfate content sometimes below the limit of sensitivity of the conventional barium sulfate method. An analytical procedure for routine sulfate determination and procedures for purification and recovery of the reagent were established.

\section{DISCUSSION OF METHODS}

\section{Barium Sulfate Method}

The ASTM method for sulfate ion in water and waste water, 5 or its equivalent, is used at the Savannah River Laboratory for surface water analyses. Glycerin, ethanol, and sodium chloride

* "Nephelometric" denotes measurement of intensity of light scattered at $90^{\circ}$; "turbidimetric," that of light transmitted. 


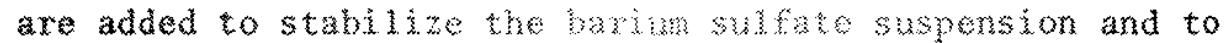

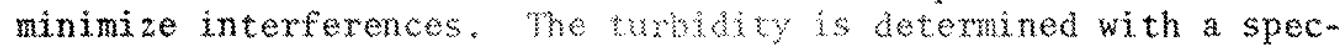

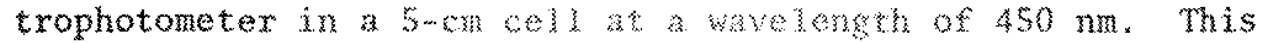

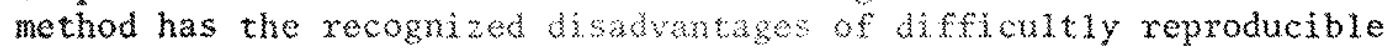
suspexsions and lack of sensiluty. Purthemore, many of the surface water samples ate yelay. Whs color trequires a large

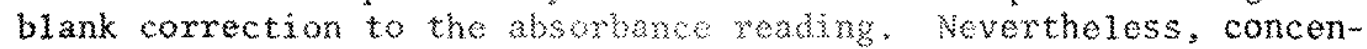
trations down to 1 phom sulare ane repreded.

\section{2-Aminoperimidine Method}

The method deserbbed by sepher" consoss of precipitation of the sulfate by adding a sacumed soluthon of 2 Ap hydrochloride

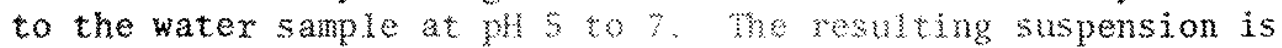

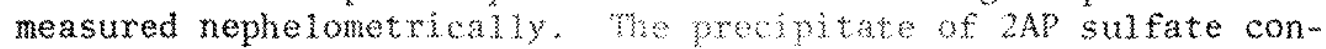

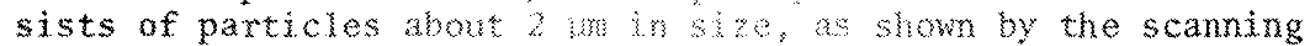

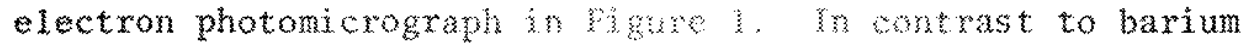

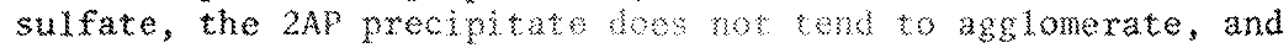

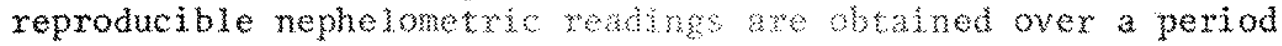
of several hours.

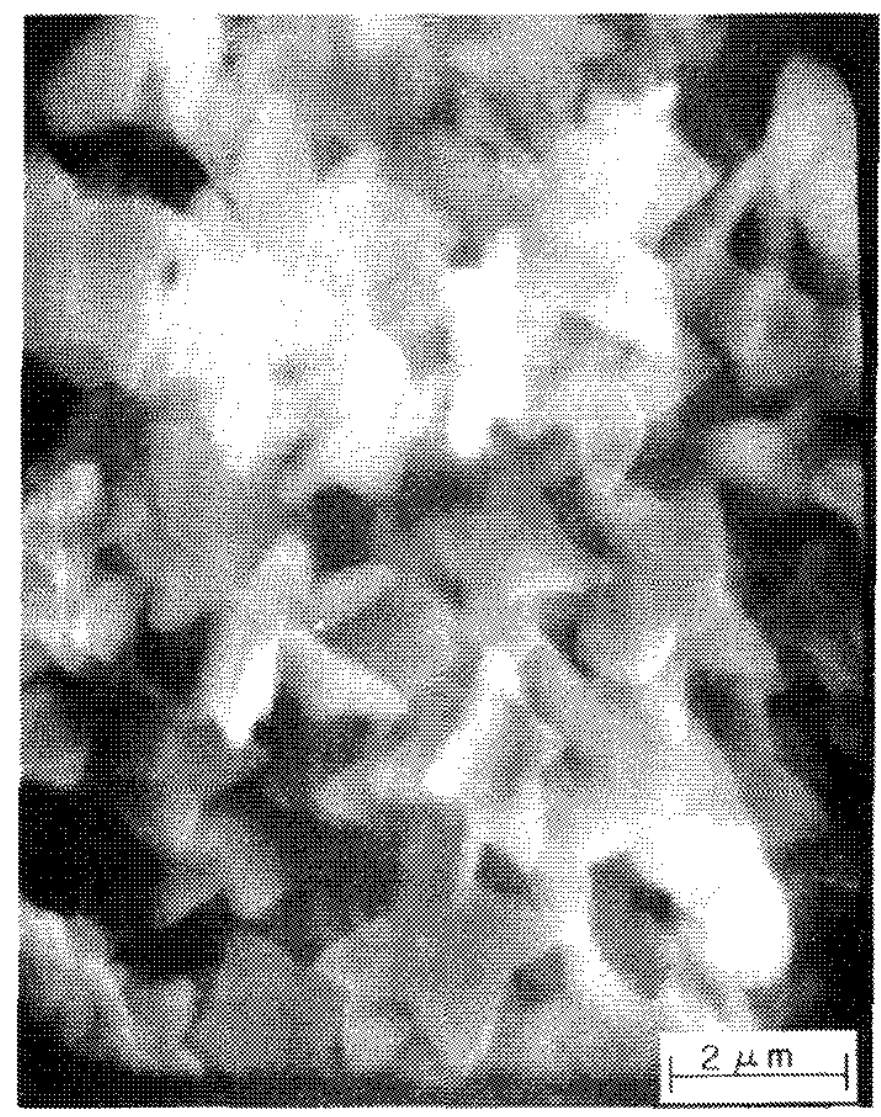

Figure 1. Scanning Electrom whombrograph of 2 Aminoperimidine Sulfate 
The analytical procedure ${ }^{2}$ had to be modified before satisfactory results were achieved. Also, procurement, purification, and recovery of the $2 \mathrm{AP}$ hydrochloride differed from those that were described. Experience and general remarks are given below, and the stepwise procedures are given in Appendix A.

Most of the 2AP hydrochloride used was prepared on special order by PCR, Inc., according to the synthesis described by Stephen. ${ }^{2}$ It was recrystallized once from methanol before use. A commercial source, G. Frederick Smith Chemical Company, provided a product which was used after it had been purified by two or three recrystallizations from methanol. Another synthesis has been published, ${ }^{6}$ which appears to be superior, but it was not tried.

Because of the expense and scarcity of the reagent, all sample and reagent solutions were saved for recovery of the $2 \mathrm{AP}$. The recommended procedure ${ }^{2}$ for recovery consisted of converting the sulfate to the soluble hydroxide and then to the chloride. This approach was abandoned because of excessive degradation when the sulfate slurry was made alkaline. The simpler procedure of salting out the 2AP hydrochloride from the completed sample solutions by adding potassium chloride was adopted.

The reagent solution consists of a nearly saturated solution of $2 \mathrm{AP}$ hydrochloride in water. More-consistent results were obtained when a small amount of sodium sulfate was added to the freshly prepared solution, and the resulting $2 \mathrm{AP}$ sulfate precipitate was filtered out. Sometimes crystals formed in the solution on standing; these had to be redissolved or filtered out before the reagent gave quantitative results.

In the formation of the sulfate suspension, results were erratic with the neutral $\mathrm{pH}$ used by Stephen. ${ }^{2}$ Above $20 \mathrm{\mu g}$ sulfate, the nephelometer reading sometimes fell far below the expected linear response. Acidification of the sample solution to $\mathrm{pH} 2$ reduced the sensitivity, but the readings were reproducible and linear with sulfate concentrations to $>30 \mathrm{\mu g}$. Variation of the $\mathrm{pH}$ within a few tenths of a unit in the region of $\mathrm{pH} 2$ did not affect the nephelometric measurements.

SRP surface waters often contained a substance that not only contributed a yellow color, but also inhibited precipitation of 2AP sulfate. The interferent was probably organic matter (humic or fulvic acids) from the vegetation the water had contacted. Pretreatment by acidification to $\mathrm{pH} 2$ and passage through a column of Amberlite* XAD-2 polymeric adsorbent ${ }^{7}$ removed the color and the interference.

* Trademark Rohm and Haas Co., Philadelphia, PA. 


\section{TEST RESULTS}

Figure 2 shows calibration curves. The ordinate is scaled in Nephelometric Turbidity Units (NTU), the unit of measurement of the instrument. The abscissa is expressed as micrograms of sulfate in the $25-\mathrm{ml}$ total volume measured. Because as much as $20 \mathrm{ml}$ of sample can be used, $10 \mathrm{\mu g}$ of sulfate, for example, could correspond to as little as $0.5 \mathrm{ppm}$ sulfate in the sample. In solutions acidified to $\mathrm{pH} \mathrm{2,} \mathrm{response} \mathrm{was} \mathrm{linear} \mathrm{up} \mathrm{to} 40 \mu \mathrm{g}$. The insert in Figure 2 details the response below $5 \mu \mathrm{g}$. The two sets of calibration points were obtained with different batches of 2AP reagent; they illustrate the need to use the same batch of reagent for calibration and sample determinations. The blank was 0.1 to $0.5 \mathrm{NTU}$.

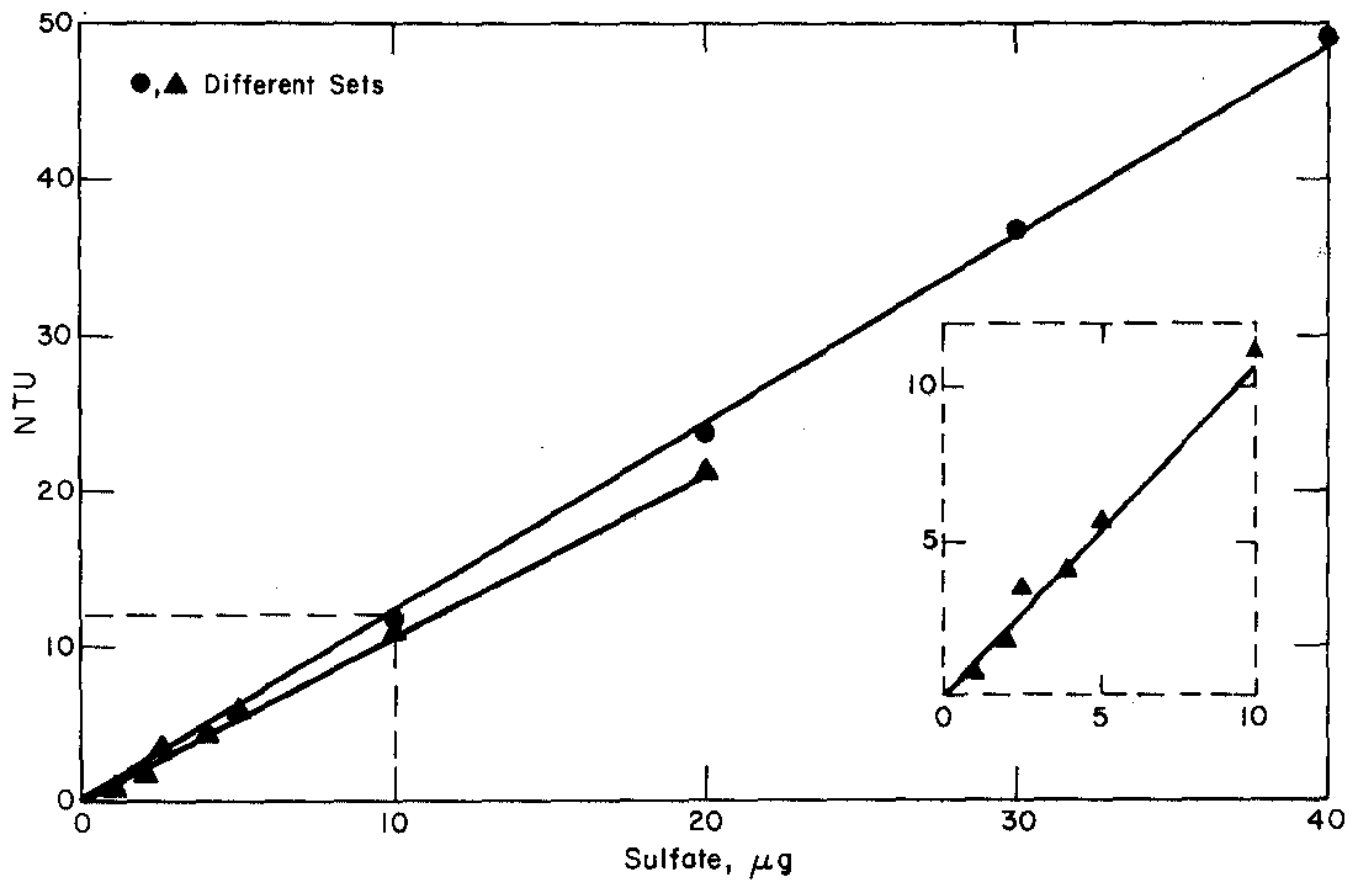

Figure 2. Calibration Curves for Nephelometric Determination of Sulfate with 2-Aminoperimidine 
Table 1 compares the results of $10 \mu \mathrm{g}$ spike recovery in surface water samples with 10 and $20 \mathrm{\mu g}$ standards, all at $\mathrm{pH} 2$. The acidified samples were pretreated by passing them through a column of Amberlite XAD-2. All are compared in terms of the slope of the linear response, as NTU/ $\mu \mathrm{g}$ sulfate. The relative standard deviation for standards and spike recovery in the water samples was 3 to $4 \%$. Although the slope for the recovered spike was $4 \%$ higher than for the standard alone, agreement is satisfactory. The precision for duplicate determinations would be $\pm 10 \%$ at the $90 \%$ confidence 1imit; this is larger than the bias between the standards and spikes. The treatment with Amberlite XAD-2 did not affect recovery of sulfate. Variation of the volume of sample did not affect the sulfate concentration found.

TABLE 1

Nephelometric Measurements in Standards and in Surface Water Samples

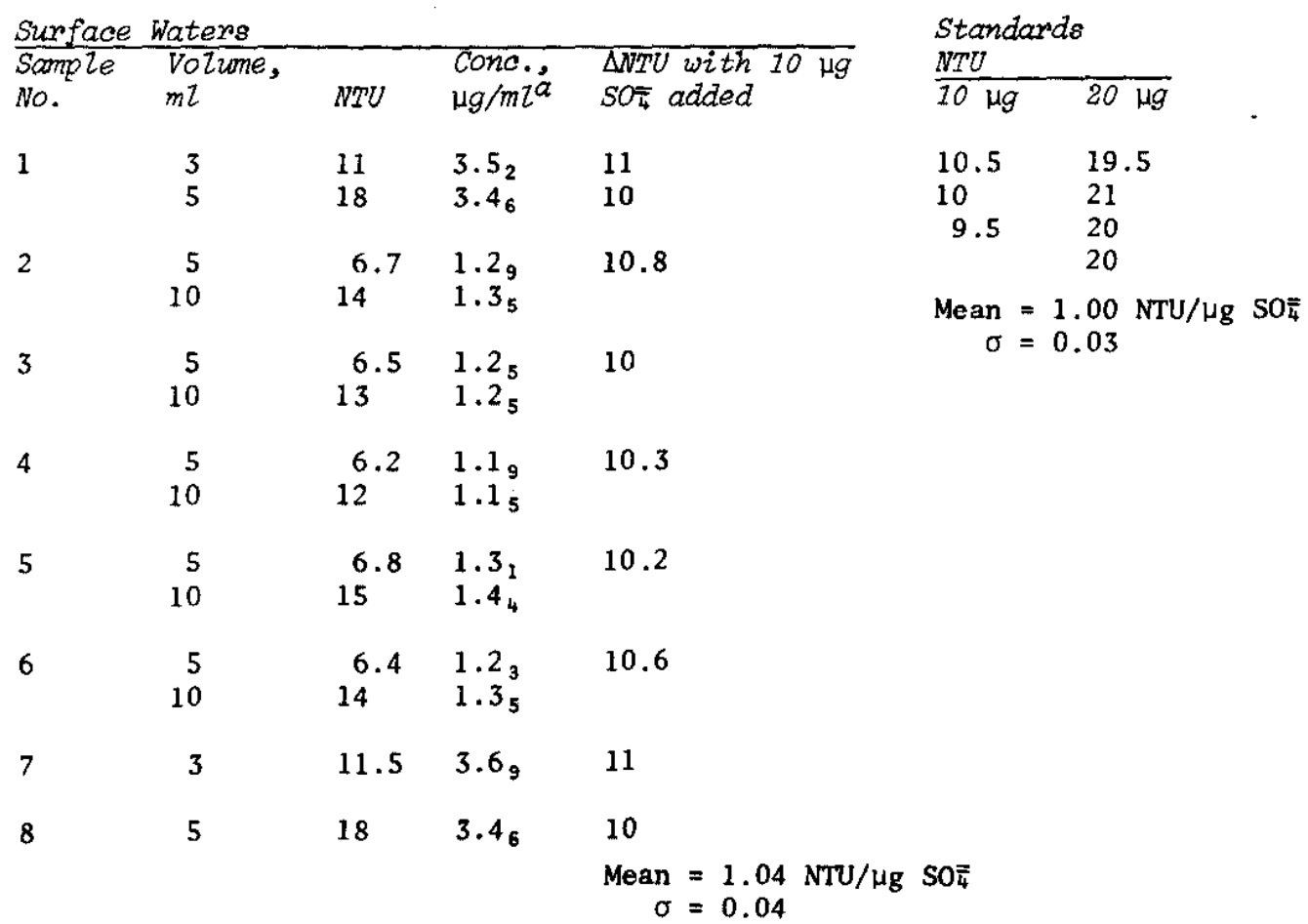

a. Calculated with $1.04 \mathrm{NTU} / \mathrm{\mu g}$ 
In Table 2, results of single sulfate determinations made by the barium sulfate and 2AP methods are compared for a series of surface waters. The table shows the effectiveness of the Amberlite XAD-2 treatment in improving the barium sulfate turbidimetric determination through removal of the color and consequent reduction of the blank correction. Without the pretreatment, many of the $\mathrm{BaSO}_{4}$ results were low compared to the 2AP. The low results and yellow color before pretreatment generally correlated. One rusty water sample had "too much color" for the $\mathrm{BaSO}_{4}$ method. The Amberlite XAD-2 column filtered out the iron colloid, permitting "<1 ppm" to be reliably determined; this result agrees with the $0.2 \mathrm{ppm}$ value obtained by the $2 \mathrm{AP}$ method.

TABLE 2

Comparison of Sulfate Determinations

Sulfate Concentration, $\mu \mathrm{g} / \mathrm{ml}$

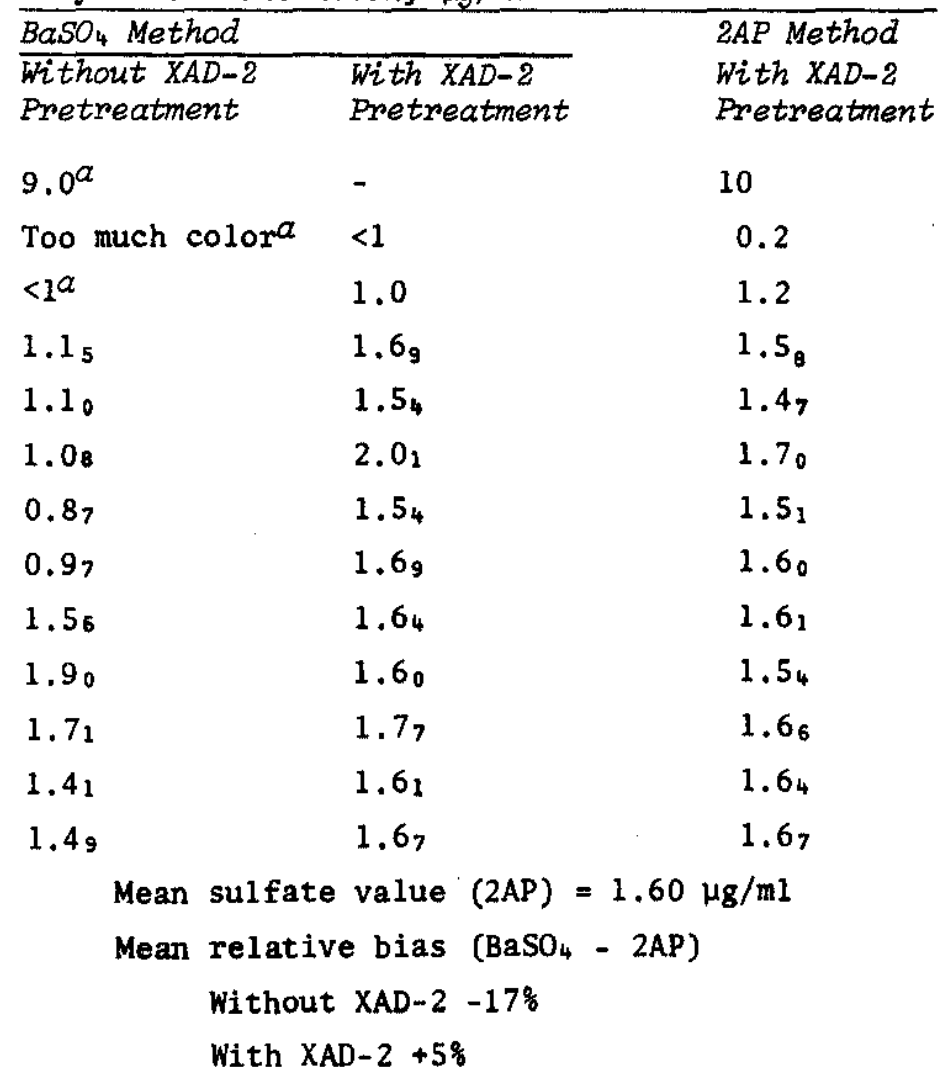

a. Not included in calculations. 


\section{APPENDIX A}

\section{EXPERIMENTAL PROCEDURE FOR NEPHELOMETRIC DETERMINATION OF SULFATE WITH 2-AMINOPERIMIDINE}

\section{Apparatus}

Hach Laboratory Turbidimeter, Model 2100A, or other nephelometer, with nephelometer tubes and turbidity standards (Hach Chemical Company, Ames, Iowa).

Millipore filter apparatus, such as Pyrex Microanalysis Frit Support, $25 \mathrm{~mm}$, Cat. No. XX10 02500 (Millipore Corporation, Bedford, Massachusetts).

MF-Millipore filter $(0.45$ micron pore size), Cat. No. HAWP 02500 .

Büchner funne1, or equivalent.

Filter paper, Whatman No. 41 .

25-ml volumetric flasks.

Micropipet, such as Digipet, $1 \mathrm{ml}$ (Manostat Corp., New York). Assorted pipets as required.

\section{Reagents}

Standard $\mathrm{Na}_{2} \mathrm{SO}_{4}$ solutions, made from oven-dried $\mathrm{Na}_{2} \mathrm{SO}_{4}$. Concentrated: $1000 \mathrm{\mu g}$ sulfate/m1 ( $\left.1.479 \mathrm{~g} \mathrm{Na}_{2} \mathrm{SO}_{4} / \mathrm{liter}\right)$. Dilute: $100 \mu \mathrm{g}$ sulfate/m1, made from concentrate.

Hydrochloric acid, 3M (1 volume concentrated HC1, 3 volumes $\mathrm{H}_{2} \mathrm{O}$ ).

Deionized water, acidified to $\mathrm{pH} 2$ (4 m1 3M $\mathrm{HCl}$ per liter).

Potassium chloride (solid reagent and $0.1 \mathrm{M} \mathrm{KC} 1$ ).

Methanol.

Diethyl ether.

2-Aminoperimidine hydrochloride, $\mathrm{C}_{11} \mathrm{H}_{9} \mathrm{~N}_{3} \mathrm{HCl}, \mathrm{m} . \mathrm{p} .282^{\circ} \mathrm{C}{ }^{1}$ 
- Purification of 2AP Hydroch1oride by Recrystallization from Methanol

1. Add about $1 \mathrm{~g}$ of $2 \mathrm{AP}$ hydrochloride to $20 \mathrm{ml}$ of boiling methanol.

2. Simmer, with stirring, until the 2AP dissolves; add a small amount more methanol if required to achieve dissolution.

3. Filter hot liquid through filter paper, such as whatman No. 41 .

4. Chill filtrate in ice about 1 hour.

5. Filter on Büchner funnel (or equivalent).

6. Wash crystals with cold methanol, then diethyl ether.

7. Air dry the gray-to-tan crystalline product.

- Preparation of $2 \mathrm{AP}$ Reagent $(0.5 \%)$

1. Add $0.125 \mathrm{~g}$ of $2 \mathrm{AP}$ hydrochloride to $25 \mathrm{ml}$ of hot water.

2. Stir to dissolve; cool to room temperature.

3. Add 1 to 2 drops of $0.1 \mathrm{M} \mathrm{Na}_{2} \mathrm{SO}_{4}$ to the cool solution.

4. Stir for about 5 minutes.

5. Filter through Millipore HAWP paper, $0.45 \mu$ porosity.

6. Store in dark glass bottle or away from light. Solution is stable several days.

Note: If crystals appear on standing (the solution is virtually saturated), they should be removed before the reagent is used. These crystals can be removed by slightly warming or filtering the solution.

- Recovery of 2AP Hydrochloride from Sample Solutions

1. After the sulfate determination, combine the solutions that contain 2AP.

2. Add enough solid $\mathrm{KCl}$ to make the solution about $1 \mathrm{M}$ in $\mathrm{KC} 1$.

3. Stir to dissolve. The solution will become turbid as the 2AP hydrochloride precipitates. 
4. Allow to stand overnight.

5. Chill in ice; filter on Büchner funnel.

6. Wash with chilled $0.1 \mathrm{M} \mathrm{KCl}$, then diethyl ether. Air dry.

\section{Procedure}

\section{Preparation of Standard Curve}

1. From micropipet, place measured volumes of dilute sulfate, standard corresponding to 1 to $30 \mathrm{\mu g}$ of sulfate in $25-\mathrm{ml}$ volumetric flasks.*

2. Dilute to about $20 \mathrm{ml}$ with acidified water.

3. Add $4 \mathrm{mI}$ of $2 \mathrm{AP}$ reagent from pipet, while swirling the solution; mix thoroughly.

4. Dilute to volume with water of $\mathrm{pH} 2$; mix again.

5. After 5 minutes, determine turbidity of the suspension with nephelometer. The suspension is stable for several hours.

6. Make a graph of NTU versus $\mu g$ sulfate, like Figure 1.

7. Save the solution after the determination for recovery of the 2AP.

Determination of Sulfate Content of Sample

1. Place volume of sample estimated to contain $<30 \mu \mathrm{g}$ sulfate in $25 \mathrm{~m} 1$ volumetric flask.

2. Dilute to $20 \mathrm{~m} 1$, with acidified water if necessary; the solution should be at $\mathrm{pH} 2$ at this point.

3. Proceed as with Steps 3, 4, 5, and 7 in "Preparation of Standard Curve."

4. Determine the $\mu \mathrm{g}$ sulfate in the sample from the standard curve and calculate the sulfate content in $\mu \mathrm{g} / \mathrm{ml}$ with the volume of sample taken in Step 1 .

* The Hach Turbidimeter tubes used required $25 \mathrm{ml}$ of solution. 


\section{APPENDIX B}

EXPERIMENTAL PROCEDURE FOR PRETREATMENT OF SURFACE

WATERS WITH "AMBERLITE" XAD-2

\section{Apparatus}

Ion exchange column, $8 \mathrm{~mm}$ OD with length to accommodate $20 \mathrm{~cm}$ column of resin.

Reagents

Amberlite XAD-2 (Rohm and Haas Co.)

Glass wool

Methanol

Procedure

Preparation and Maintenance of the Amberlite XAD-2 Column?

1. Wash the resin, as received from the manufacturer, by slurrying and decanting several times in water to remove the fines and the $\mathrm{KCl}$ mold retardant.

2. Transfer to ion exchange column enough resin to form a column about $20 \mathrm{~cm}$ 1ong.

3. Wash column with $10 \mathrm{ml}$ water at about $1 \mathrm{ml} / \mathrm{min}$, but do not allow the level of the liquid to drop below the top of the resin at any time during the procedure.

4. Wash with about $10 \mathrm{ml}$ methanol at about $1 \mathrm{ml} / \mathrm{min}$.

5. Backflush the column with water to remove air bubbles that appear during the methanol wash.

6. Repack the column by allowing the resin to settle under water. Then wash the column with another $10 \mathrm{ml}$ of water, downflow.

7. Place a plug of glass wool in the top of the column to hold the resin in place. (The glass wool also protects the column from contamination by particulates from unfiltered samples.) Replace the glass wool as required. 
8. The column is now ready for use and can be used for sequential samples until the yellow color extends about 1/4 the length of the column. Then regenerate the column with about $20 \mathrm{ml}$ of methanol and proceed from Step 5.

Pretreatment of Surface Waters

1. To $50 \mathrm{ml}$ of sample, add $200 \mu 1$ of $3 \mathrm{M} \mathrm{HC1}$.

2. Pour about $5 \mathrm{~m} 1$ of the solution into the Amberlite XAD-2 column and pass it through at about $1 \mathrm{ml} / \mathrm{min}$. Discard effluent.

3. Transfer remaining solution to column; pass through at about $1 \mathrm{ml} / \mathrm{min}$. Use this effluent for sulfate determination. 


\section{REFERENCES}

1. I. M. Kolthoff, E. B. Sande11, E. J. Meehan, and S. Bruckenstein. "Determination of Sulfur as Barium Sulfate." Quantitative Chemical Analysis, Fourth Edition, Chapter 27. The Macmillan Company, Collier-Macmillan Limited, London (1969).

2. W. I. Stephen. "A New Reagent for the Detection and Determination of Small Amounts of the Sulphate Ion." Anal. Chim. Acta 50, 413 (1970).

3. P. A. Jones and W. I. Stephen. "The Indirect Spectrophotometric Determination of the Sulphate Ion with 2-Aminoperimidine." Anal. Chim. Acta 64, 85-92 (1973).

4. R. F. Maddalone, G. L. McClure, and P. W. West. "Determination of Sulfate by Thermal Reduction of Perimidylammonium Sulfate." Anal. Chem. 47, 316 (1975).

5. "Standard Methods of Test for Sulfate Ion in Water and Waste Water." 1976 Annual Book of ASTM Standards, Part 31, Water, ASTM-D-516, p 429, American Society for Testing Materia1s, Philadelphia, PA (1976).

6. G. L. McClure. "An Improved Synthesis of 2-Perimidylammonium Ion for Use as a Sulfate Reagent." Anal. Chim. Acta 64, 289 (1973).

7. Amberlite XAD-2. Technical Bulletin, Ion Exchange Department, Rohm \& Haas Co., Philadelphia, PA. 
INTERNAL DISTRIBUTION

\author{
Copy \\ No. \\ 1-3. T. B. Niland, SR \\ 4. J. D. Ellett, Wilm \\ 5. F. E. Kruesi - J. F. Proctor \\ 6. R. E. Naylor - L. C. Evans \\ 7. H. F. Ring \\ 8. W File \\ 9. L. F. Shafranek, Eng Dept \\ 10. W. J. Mottel - R. Maher, SRP \\ 11. S. Mirshak \\ 12. T. C. Evans - E. L. Graf \\ 13. C. M. Patterson - H. A. McClearn \\ 14. L. B. Smith \\ 15. C. H. Ice - L. H. Meyer, SRL \\ 16. H. J. Groh \\ 17. R. L. Folger \\ 18. T. V. Crawford \\ 19. L. J. Tilly \\ 20. M. Y. Donnan \\ 21. R. S. Dorsett \\ 22. J. E. Conner \\ 23. S. F. Peterson \\ 24. E. W. Baumann \\ 25. F. H. Springer \\ 26. TIS Record Copy \\ SPECIAL DISTRIBUTION \\ 27. J. P. Giesy, SREL
}


Form AEC 426

$(5-74)$

AECM 3201
U.S. ATOMIC ENERGY COMMISSION

MAJOR CONTRACTOR'S RECOMMENDATION FOR

DISPOSITION OF SCIENTIFIC AND TECHNICAL DOCUMENT

* See Instructions on Reverse

1. AEC Report No.

$$
\text { DP }-1437
$$

2. Subject Category No.

$$
\mathrm{UC}-4
$$

3. Title

Nephelometric Determination of Microgram Quantities of Sulfate With 2-Aminoperimidine

4. Type of Document (" $X$ " one)

[Q a. Scientific and Technical Report

$\square$ b. Conference paper:

Title of conference

Date of conference

Exact location of conference

c. Other (Specify. Thesis, Translation, etc.)*

5. Copies Transmitted ("X" one or more)

(4) a. Copies being transmitted for standard distribution by AEC-TIC.

$\square$ b. Copies being transmitted for special distribution per attached complete address list.*

[. Two completely legible, reproducible copies being transmitted to AEC-TIC.

6. Recommended Distribution (" $X$ " one)

[X. Normal handling (after Patent clearance): no restraints on distributionexcept as may be required by the security classification.

$\square$ b. Make avaitable oniy to U.S. Government agencies and their contractors.

C. Make availabie only within AEC and to AEC contractors.

[] d. Make available only within AEC.

$[$ e. Make available only to those listed in item 12 below.

$\square$ f. Other (Spectfy)*

7. Recommended Announcement (" $X$ " one)

DX. Normal procedure may be followed.*

b. Recommend following announcement limitations:

8. Reason for Restrictions Recommended in 6 or 7 above.

a. Protirninary information.

$\square$ b. Prepared primarily for internal use.

[] c. Other (Explain)

9. Patent Clearance " $X$ " one)

X] a. AEC patent clearance has been granted by responsible AEC patent group.

$\square$ b. Document has been sent to responsible AEC patent group for clearance.

13. National Security Information (For classified document only; " $X$ " one)

$\square$ a. Document does contain national security information other than restricted data.

b. Document does not contain national security information other than restricted data.

11. Copy Reproduction and Distribution

a. Total number of copies reproduced $183+25$

b. Number of copies distributed outside originating organization $\_156$

12. Adaitional Information or Remarks (Continue on separate sheet, if necessary)

13. Submitted by (Name and Position) (Please print or type)*

E. H. Springer, Publications Supv.

14. Organization

Savannah River Laborfatory

15. Signature

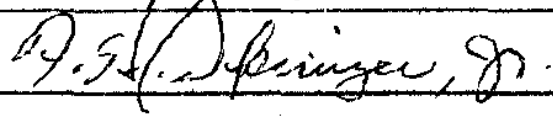

16. Date

$12 / 5 / 96$ 

$\begin{array}{cl}\text { Description of Material } & \text { No. } \frac{\mathrm{DP}-1437}{\text { Title: }} \begin{array}{l}\text { Nephelometric Determination of Microgram Quantities of Sulfate with } \\ \text { 2-Aminoperimidine }\end{array}\end{array}$

Author(s): Elizabeth W. Baumann

\section{Type of Materlal}

[ ] Classified DP Roport

[X] Unclassified DP Report

[ ] Classifiod Letter

[ ] Unclassified Letter
[] Classifiod Paper

[ ] Unclassified Paper

[1 Classified Abstract or Summary

[ ] Unclassified Abstract or Summary

\section{Technical Content}

Approved by

\section{Classification}

Approved by

Approved by

Authority

R. L. Folger
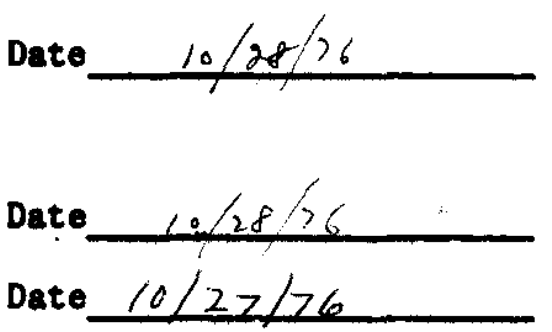

Topic 5.1.1 CG-UF-2

Topic 705.1 SR Classification Guide

\section{Category if DP Report}

Approved by

\section{Supervisor, TIS}

Date

\section{Final Du Pont Release}

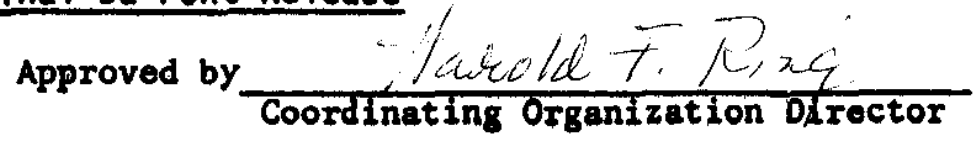

Date $/ 1-4-70$

Released by:

A. F. Westerdahl: $11 / 2 / x$ 


\section{DISTRIBUTION}

Copy

1-3 T. B, Niland, ERDA-SR

4-26 TIS File, SRL

27 J. P. Giesy, SREL

28-183 ERDA-TIC

(for distribution under TID-4500 Category UC-4) 